\title{
Millennials' Career Decision-Making Difficulties (CDMD) IN Indonesian University Students
}

\author{
Erni Murniarti \\ Educational Management Program, \\ Universitas Kristen Indonesia \\ Lydia Irene Siahaan \\ Communication student, \\ Telkom University
}

\begin{abstract}
Though millennial has unique characteristics as digital natives who prefer to interact with images, branded goods, to have idols and who are interested in modern technological utilization, studying their career decision-making difficulties (CDMD) is barely reported in Indonesia. To respond to such gap, the current report was designed to pattern the CDMD of both male $(N=120)$ and female $(N=140)$ undergraduate students in Indonesia. The instrument of the research was totally adopted from Gati et al's. (1996) career decision-making difficulties questionnaire. Descriptive anaylsis showed that the male $(M=4.93)$ have higher difficulties than the females $(M=4.85)$. With different levels of difficulties, the current study, therefore, corresponds to Mau's (2004), Guan et al's. (2015), and di Fabio, Palazzeschi, Levin, Levin, and Gati's (2015) reports.
\end{abstract}

Keywords: career decision-making difficulties, Indonesian university students, millennial

\section{INTRODUCTION}

Prior to job performance, job seekers, fresh graduates, and undergraduate students need to decide a preferred job type. Aside from the development of the effectiveness and efficiency of career counseling (Gati \& Levin, 2014) performed by professionals, it is due to the fact that the career decision is significant for individual and society (Gati, Krausz, \& Osipow, 1996). It is also because people with good career plans are more likely to have lower career decision-making difficulties (henceforth CDMD), and higher career decision-making self-efficacy and vocational decision-making style (Amir \& Gati, 2006).

Regardless of extensive study on the CDMD pioneered by Gati, Krausz, and Osipow (1996), it is certain to conclude that people are more likely to have different levels of the CDMD, and are monitored by various variables across countries. Mau (2004), for example, studied the CDMD of White, African, Hispanic, and Asian American high school and university students in U.S. It was reported that Asian Americans outperformed career decision-making difficulties, and White American perceived the fewest obstacles. Compared to Americans, Guan et al. (2015) emphasized that Chinese undergraduates had a better ability in consulting, desire to please others, willingness to compromising, dependence, procrastination, and have lower aspiration for occupation, internal locus of control, and decision making. In light of the Chinese consulting with others, Willner et al. (2015) reported that it is used to reduce the CDMD. Moreover, di Fabio, Palazzeschi, Levin, Levin, and Gati, 2015) claimed that for Italian young adults, university students are more likely to have less developmental career indecision that of high school students and on-the-job training (OJT) interns. 
To do with the various predictors of the CDMD, many scholars have studied them for decades and showed various results. More recently, Brown, George-Curran, and Smith (2003) have made it obvious that sex was not a moderator variable to the influence of emotional intelligence towards career decision-making self-efficacy. However, it is critical to effect career development (Salami, 2010). Furthermore, three theoretical factors of a career indecision according to Germeijs and De Boeck (2003) are information, valuation, and outcomes, but only the last two factors are more influential to the career indecision. Reducing the CDMD, Storme and Celik (2018) accentuated that a career exploration is found more useful to attenuate the CDMD if the individuals have a good motivation. Finally, studying the effect of parenting styles on adolescents' career decision-making of French and South Korea, Sovet and Metz (2014) stated that an authoritarian parenting style positively influenced career decision self-efficacy, but had lower effect on career.

Despite the influence of the industrial revolution 4.0 signaled by a single network system (Nagy, Oláh, Erdei, Máté, \& Popp, 2018) and the characteristics of millennial (Miller, Hodge, Brandt, \& Schneider, 2013) as digital natives (Presnky, 2005) who prefer to interact with images, branded goods, to have idols (KPMG, 2017) and who are interested in modern technological utilization (Crappell, 2012; Corriveau \& Shi, 2010), the CDMD is barely reported by Indonesian researchers. It has become questionable as a social entrepreneurship has been treated as one of the solutions to increase Indonesian economic growth and social development (Suyatna \& Nurhasanah, 2018). To do with the social media literacy with its function in profiling job seekers (Kajanová, Sedláček, \& Soósová, 2017), Indonesian students' social media literacy at STIKOP LSPR Jakarta with varied levels across gender (Rastati, 2018) was found moderate (Sholikhati, 2018). More surprisingly, the Indonesian millennials are unlikely to be intrinsically motivated in career decision making (Akosah-Twumasi, Emeto, Lindsay, Tsey, \& Malau-Aduli, 2018) as they are non-bicultural individuals. Such problem has been getting worse as the levels of the CDMD are notably different across countries and cultures (Gati et al., 1996; Mau, 2004; Guan et al., 2015; di Fabio et al., 2015) and are influenced by various variables (Brown et al., 2003; Salami, 2010; Germeijs \& De Boeck, 2003; Storme \& Celik, 2018; Sovet \& Metz, 2014). To respond the gap, the present article addresses the CDMD of undergraduate students as the generation-Y in Jakarta.

\section{Negative Characteristics of Millennial}

\section{LITERATURE REVIEW}

Millennial is a new demographic cohort in the $21^{\text {st }}$ century. It is due to the fact that they with the most radical change in ideology (Huyler, Pierre, Ding, \& Norelus, 2015) have their own characteristics that appear to be different from the other generation. The millennials, those who were born in the 1980s and 1990s (Miller et al., 2013), are open-minded, but neurotic (Ordun \& Akun, 2016). Moreover, they have three basic problems, such as concentration, engagement, and socialization (Karakas, Manisaligil, \& Sarigollu, 2015). As to critical thinking, a survey conducted by Spitzer et al. (2015) to 800 millenial management executives who were came from 50 different industries showed that almost one in five participants had low analytical skills.

In the workplace, Lykins and Pace (2013) reported that the millennials, in addition to leadership skill, lack social competence. This is in line with $\mathrm{Ng}$, Schweitzer, and Lyons' (2010) claim that the millennials found individualistic aspect of job more important that of the others. Regarding the leadership, Faller and Gogek (2019) said that they have a unique attitude on it. They view that the good leadership is achievable when they can perform group or teamwork, communication, respect, vision, and influence (Graybill, 2014). 
Contextualizing it in teaching and learning, it can be inferred that today's faculty should incorperate numerous challenges in teaching the millenial (Mitchell, 2012). It results from millennial's preference leaning method. Suggested by Hampton, Pearce, and Moser (2017), it is stated that the millennial prefer to learn through simulation. This indicates that today's leaners are more likely to study with contexts existing in their own lives (Au-Yong-Oliveira, Gonçalves, Martins, and Branco, 2018). In realizing such factual learning, Au-Yong-Oliveira et al. (2018) highly recommend the use of information technology in the classroom.

\section{Positive Characteristics of Millennial}

Characterized as digital natives (Presnky, 2005; Moore, 2010), they are in great need of modern technological utilization (Crappell, 2012; Corriveau \& Shi, 2010). This influences, aside from having idols, their interest in images and branded goods (KPMG, 2017). As for the brands, de Kerviler and Rodriguez (2019) have proved that 262 participants of their study received more motivation and sense of selves through the luxury brands of the goods.

Effected by personal characteristics and social factor (Purani, Kumar, \& Sahadev, 2019), the millennials believe in the power of motivation (Au-Yong-Oliveira et al., 2018). More specifically, they are more likely to be motivated by gain sharing (GS) in their workplace, a balance between workplace reality and expectations. Accentuated by Queiri, Dwaikatt, Fadzilah, Yusoff, and Dwaikat, (2015), the dissatisfaction of Malaysian generation-Y workforce is highly related to the relevance between payment and work performance. Another vitally important of the millennials' motivation is the influence of their role models and peers (Price, McGillis Hall, Murphy, \& Pierce, 2018).

\section{Related Studies on the CDMD of the Millennial}

The career decision-making is not an easy work to do. For some reasons, it requires emotional intelligence, professional commitment, self-efficacy, and decision-making adaptability. Accentuated by Santos, Wang, and Lewis (2018), it is certain (Di Fabio, Palazzeschi, \& Bar-On, 2012) to have high emotional intelligence to reduce the CDMDs. Through goal commitment and professional commitment, the emotional intelligence positively predicts the self-efficacy in the career decision-making (Jiang, 2016). As for the decision-making adaptability, it was reported that people with the good career decision-making adaptability appeared to have fewer difficulties prior to and during the career decision-making process (Willner et al., 2015). Finally, to achieve the good career, it is obliged, mediated by career decision-making selfefficacy, to be supported by parents and teachers (Garcia, Restubog, Bordia, Bordia, \& Roxas, 2015)

Many studies on the CDMDs have been reported. Most notably, di Fabio et al's. (2015) finding revealed that university students had less career indecision that of high school students. It is, therefore, is in accordance with Sidiropoulou-Dimakakou, Mylonas, Argyropoulou, and Drosos' (2013) discovery that the millennials seemed to perform low uncertainty and fear of future careers. The future work is viewed as someone's hopes and aspirations that she or he is going to do (Strauss, Griffin, \& Parker, 2012). Lastly, compared to Americans, Guan et al. (2015) emphasized that Chinese undergraduates had a better ability in consulting, desire to please others, willingness to compromising, dependence, procrastination, and have lower aspiration for occupation, internal locus of control, and decision making.

\section{Participants}

\section{RESEARCH METHOD}

The objective of the current study was to pattern the CDMD performed by the undergraduate students in Jakarta, Indonesia. Using a purposive sample method, 260 students consisting of 
200 private university students and 60 state university students were the participants of the study. They are between the ages of 18 and 24 (Mean =20.73), 140 females and 120 males.

\section{Instrument}

The instrument of the research was totally adopted from Gati et al's. (1996) career decisionmaking difficulties questionnaire. It was a 9-point-rated questionnaire. The CDDQ contains 44 items related to the Gati et al.'s taxonomy. Furthermore, such instrument has been validated by researchers from different countries. Tien (2005) validated the career decision-making difficulties in the Chinese culture, and Babarović and Šverko (2018) did it in Croasia to 451 and 568 participants. The results showed that career decision-making questionnaire (henceforth CDDQ) were reliabe and structurally equivalent measure. Gati et al. (1996) reported that median Cronbach $\alpha$ reliabilities of the instrument were 0.78 and 0.77 and Osipow and Gati (1998) have claimed similar reliabilities. The median Cronbach reliability was 0.76 with range of 0.67-0.68.

\section{Procedure of Data Collection and Analysis}

Prior to the self-reporting CDMD, the researcher explained the purpose of the research "to pattern the undergradute students' career decision-making difficulties in Jakarta, Indonesia." Wihtout any refusals, the undergraduate students were asked to report their CDMD through the designed questionnaire.

After collecting the data, they were then scored in Excel 2013. To display the sample' CDMD, the calculated data were tabulated in table and figures showing the mean and standard deviation according the taxonomy. Finally, to support the findings and emphazie the claim, the finding was discussed by referring to previous studies and theories.

\section{Research Results}

\section{RESEARCH RESULTS AND DISCUSSION}

Table 1. Career Decision-Making Difficulties of Indonesian Students

\begin{tabular}{|c|c|c|c|c|c|}
\hline \multirow[b]{2}{*}{ CDDQ Scale } & \multirow{2}{*}{ No of Items } & \multicolumn{2}{|c|}{ Male } & \multicolumn{2}{|c|}{ Female } \\
\hline & & $\mathbf{M}$ & SD & $\mathbf{M}$ & SD \\
\hline \multicolumn{6}{|l|}{ Lack of Readiness } \\
\hline Lack of Motivation (Rm) & 3 & 5.18 & 1.96 & 5.06 & 1.99 \\
\hline Indecisiveness (Ri) & 4 & 4.30 & 2.02 & 5.36 & 2.13 \\
\hline Dysfunction Myths (Rd) & 3 & 5.55 & 2.43 & 5.07 & 2.29 \\
\hline \multicolumn{6}{|l|}{ Lack of Information } \\
\hline Lack of Knowledge about the Process of CDM (Lp) & 3 & 4.20 & 2.42 & 4.36 & 2.19 \\
\hline Lack of Information about Self (Ls) & 8 & 4.67 & 1.83 & 4.42 & 1.92 \\
\hline Lack of Information about Occupation (Lo) & 4 & 6.50 & 1.68 & 5.94 & 1.80 \\
\hline $\begin{array}{l}\text { Lack of Information about Ways of Obtaining } \\
\text { Additional Information (La) }\end{array}$ & 2 & 6.26 & 1.15 & 5.97 & 1.69 \\
\hline \multicolumn{6}{|l|}{ Inconsistent Information } \\
\hline Unreliable Information (Iu) & 6 & 5.44 & 2.12 & 5.31 & 2.13 \\
\hline Internal Conflicts (Ii) & 7 & 4.30 & 1.75 & 4.27 & 1.92 \\
\hline External Conflicts (Ie) & 4 & 4.13 & 1.64 & 3.88 & 1.72 \\
\hline Lack of Readiness & 10 & 4.94 & 2.20 & 5.18 & 2.14 \\
\hline Lack of Information & 17 & 5.20 & 2.06 & 4.81 & 2.06 \\
\hline Inconsistent Information & 17 & 4.66 & 1.95 & 4.54 & 2.04 \\
\hline Total & 44 & 4.93 & 2.07 & 4.85 & 2.08 \\
\hline
\end{tabular}


As shown in Table 1. that male undergaduate students $(M=4.9)$ were more ready facing their future career that of the females $(M=5.18)$. Among three indicators, however, dysfunction myths and lack of motivation were outperformed by the females. As for lack of information, the male reported that they had less information regarding to their future career $(M=5.20$, which means more than half of them did not have enough information about what job types they are going to do. Referring to the aspects of the lack of information, only lack of knowledge about the process of CDM (Lp) did the females more experience (4.36). Furthermore, similar to information problem, the male also had problem with inconsistent information (4.66), slighly higher than the females' (5.54).

\section{DISCUSSION}

As far as the career readiness is concerned, it is certain that both male and female performed different levels of career readiness (Durosaro \& Adebanke, 2012). In the current study, the male undergaduate students $(M=4.9)$ were more ready facing their future career that of the females $(M=5.18)$. Though it still needs further empirical data, this indicates that the males received more benefits on their university performance (Teck Heang Lee, 2012), and parnerhsips and conferences they have ever participated (Besnoy, Clayton-Code, \& Whitman, 2012).

Treated as the indicator of lack of readiness, the career motivation of the young females were found better. It is, therefore, in line with Leung and Clegg's (2001) finding that younger executives $(n=19)$ performed better career motivation that of senior executives $(n=11)$. In addition, the female's career motivation, though higher, is slightly different with the males' (5.18). It means that gender is unlikely to be a predictor of work motivation (S. C. Chai, Teoh, Razaob, \& Kadar, 2017). Regardless of this, it is discovered that the career motivation of the females is averagely 5.04. This suggests, therefore, an career motivation improvement for them (X. Chai, Cheng, Mei, \& Fan, 2019).

As for lack of information, the male reported that they had less information regarding to their future career $(M=5.20)$, which means more than half of them did not have enough information about what job types they are going to do. This indicates that the role job vacancy is not very much received by the males, and are not used as navigators in their future career, an opportunity to look for an appropriate colleague and company (Stonebraker, Maybee, \& Chapman, 2019). Such condition is likely to be influenced by negative job search experiences (Kreemers, van Hooft, \& van Vianen, 2018) and licence ownership and educational background (Fransen, Deruyter, \& De Maeyer, 2018) of the undergraduate students.

Moreover, referring to the aspects of the lack of information, only knowledge about the process of CDM (Lp) did the males more experience (4.20). The other types, like information about self, occupation and ways of obtaining additional information are more likely performed by the females. This higlights that the females prefer to do self-reflection which is useful to predict their self-companssion (Viskovich \& De George-Walker, 2019). In addition, it also suggests that females are more aware of work maturity and have more positive attitude on career. To show their readiness and career maturity, many of them were found part-timers (Waaijer, Sonneveld, Buitendijk, Van Bochove, \& Van Der Weijden, 2016).

Furthermore, similar to the information problem, the male also had problem with inconsistent information (4.66), slighly higher than the females' (5.54). In three ways, the male undergraduate students reported their inconsistent information about the career. They perceived more unreliable information (5.44), and had more both internal (4.30) and external conflicts (4.13). The male's unreliable information, so-called fake news, can be influneced by 
social media (Park \& Rim, 2019) and cognitive ability. However, with higher level of cognitive ability, the such incorrent information about is more likely to be more adjusted (De keersmaecker \& Roets, 2017) by the male undergraduate students.

Overall, it is certain to claim that the Indonesian male undergraduate students have more problem in deciding their future career (4.93) that of the females (4.85). Averagely, they have 4.89 CDMD index which means that more than a half of the the Indonesian millenials persuing their undergradute programs encounter problem in deciding what job types they will perform. As Asian people, such finding is supported by previous studies. Mau (2004) claimed that Asian Americans outperformed career decision-making difficulties. Similar to the Mau's, Guan et al. (2015) reported that Chinese undergraduates had higher problem in deciding their future career. Unlikely, di Fabio, Palazzeschi, Levin, Levin, and Gati, 2015) claimed that for Italian young adults, university students are more likely to have less developmental career indecision that of high school students and on-the-job training (OJT) interns.

\section{CONCLUSION}

The objective of the current study is to pattern the CDMD of the Indonesian millenials, both male and female, who are persuing their undergradute programs in private and state universities. The descriptive analysis revealed that the Indonesian male undergraduate students have more problems in deciding their future career that of the females. Averagely, they have 4.89 CDMD index which means that more than a half of the the Indonesian millenials persuing their undergradute programs encounter problem in deciding what job types they will perform. As Asian people, with different levels of difficulties, the finding of the research therefore is in line with previous studies conducted by Mau (2004), Guan et al. (2015), and di Fabio, Palazzeschi, Levin, Levin, and Gati (2015). To do with this, it is suggested to seriously conduct a workshop on the process of the CDM for the undergraduate students in Indonesia in order that they have great self-confidence to decide what job types they will perform in the future.

\section{ACKNOWLEDGMENTS}

The current report has been fullt funded by Universitas Kristen Indonesia. I am so thankful for Saniago Dakhi's help in reviewing the article.

\section{References}

Akosah-Twumasi, P., Emeto, T. I., Lindsay, D., Tsey, K., \& Malau-Aduli, B. S. (2018). A Systematic Review of Factors That Influence Youths Career Choices-the Role of Culture. Frontiers in Education.

https://doi.org/10.3389/feduc.2018.00058

Amir, T., \& Gati, I. (2006). Facets of career decision-making difficulties. British Journal of Guidance and Counselling. https://doi.org/10.1080/03069880600942608

Au-Yong-Oliveira, M., Gonçalves, R., Martins, J., \& Branco, F. (2018). The social impact of technology on millennials and consequences for higher education and leadership. Telematics and Informatics.

https://doi.org/10.1016/j.tele.2017.10.007

Babarović, T., \& Šverko, I. (2018). The Validity of Career Decision-Making Difficulties Questionnaire in Croatia. Journal of Career Assessment. https://doi.org/10.1177/1069072717748960

Besnoy, K., Clayton-Code, K., \& Whitman, M. (2012). Developing College and Career Readiness Through the Man Up! Men's Leadership Summit. Journal of Career and Technical Education.

https://doi.org/10.21061/jcte.v28i1.570

Brown, C., George-Curran, R., \& Smith, M. L. (2003). The Role of Emotional Intelligence in the Career Commitment and Decision-Making Process. Journal of Career Assessment. https://doi.org/10.1177/1069072703255834

Chai, S. C., Teoh, R. F., Razaob, N. A., \& Kadar, M. (2017). Work motivation among occupational therapy graduates in Malaysia. Hong Kong Journal of Occupational Therapy. https://doi.org/10.1016/j.hkjot.2017.05.002 
Chai, X., Cheng, C., Mei, J., \& Fan, X. (2019). Student nurses' career motivation toward gerontological nursing: A longitudinal study. Nurse Education Today. https://doi.org/10.1016/j.nedt.2019.01.028

Corriveau, J.-P., \& Shi, W. (2010). Teaching strategies to millenial students. https://doi.org/10.1145/1920778.1920799

Crappell, C. (2012). Millennials In Action: Playing To Our Strengths. American Music Teacher.

De keersmaecker, J., \& Roets, A. (2017). 'Fake news': Incorrect, but hard to correct. The role of cognitive ability on the impact of false information on social impressions. Intelligence. https://doi.org/10.1016/j.intell.2017.10.005

de Kerviler, G., \& Rodriguez, C. M. (2019). Luxury brand experiences and relationship quality for Millennials: The role of self-expansion. Journal of Business Research. https://doi.org/10.1016/j.jbusres.2019.01.046

Di Fabio, A., Palazzeschi, L., \& Bar-On, R. (2012). The role of personality traits, core self-evaluation, and emotional intelligence in career decision-making difficulties. Journal of Employment Counseling.

https://doi.org/10.1002/j.2161-1920.2012.00012.x

di Fabio, A., Palazzeschi, L., Levin, N., Levin, N., \& Gati, I. (2015). The Role of Personality in the Career DecisionMaking Difficulties of Italian Young Adults. Journal of Career Assessment.

https://doi.org/10.1177/1069072714535031

Durosaro, I., \& Adebanke, M. (2012). Gender as a Factor in the Career Choice Readiness of Senior Secondary School Students in Ilorin Metropolis of Kwara State, Nigeria. International Journal of Humanities and Social Science.

Faller, M., \& Gogek, J. (2019). Break From the Past: Survey Suggests Modern Leadership Styles Needed for Millennial Nurses. Nurse Leader. https://doi.org/10.1016/j.mnl.2018.12.003

Fransen, K., Deruyter, G., \& De Maeyer, P. (2018). The impact of driver's license ownership on unemployed job seekers' access to job openings: Assessing the driver's license at School project in Flanders. Case Studies on Transport Policy. https://doi.org/10.1016/j.cstp.2018.08.008

Garcia, P. R. J. M., Restubog, S. L. D., Bordia, P., Bordia, S., \& Roxas, R. E. O. (2015). Career optimism: THE roles of contextual support and career decision-making self-efficacy. Journal of Vocational Behavior.

https://doi.org/10.1016/j.jvb.2015.02.004

Gati, I., Krausz, M., \& Osipow, S. H. (1996). A Taxonomy of Difficulties in Career Decision Making. Journal of Counseling Psychology. https://doi.org/10.1037/0022-0167.43.4.510

Gati, I., \& Levin, N. (2014). Counseling for career decision-making difficulties: Measures and methods. Career Development Quarterly. https://doi.org/10.1002/j.2161-0045.2014.00073.x

Germeijs, V., \& De Boeck, P. (2003). Career indecision: Three factors from decision theory. Journal of Vocational Behavior. https://doi.org/10.1016/S0001-8791(02)00055-6

Graybill, J. O. (2014). Millennials among the professional workforce in academic libraries: Their perspective on leadership. Journal of Academic Librarianship. https://doi.org/10.1016/j.acalib.2013.09.006

Guan, Y., Chen, S. X., Levin, N., Bond, M. H., Luo, N., Xu, J., ... Han, X. (2015). Differences in Career Decision-Making Profiles Between American and Chinese University Students: The Relative Strength of Mediating Mechanisms Across Cultures. Journal of Cross-Cultural Psychology. https://doi.org/10.1177/0022022115585874

Hampton, D., Pearce, P. F., \& Moser, D. K. (2017). Preferred Methods of Learning for Nursing Students in an OnLine Degree Program. Journal of Professional Nursing. https://doi.org/10.1016/j.profnurs.2016.08.004

Huyler, D., Pierre, Y., Ding, W., \& Norelus, A. (2015). Millennials in the Workplace: Positioning Companies for Future Success. 14th Annual South Florida Education Research Conference.

Jiang, Z. (2016). Emotional Intelligence and Career Decision-Making Self-Efficacy: Mediating Roles of Goal Commitment and Professional Commitment. Journal of Employment Counseling. https://doi.org/10.1002/joec.12026

Kajanová, H., Sedláček, M., \& Soósová, V. (2017). Attitudes of young people to job searching through social media: Case of Slovakia. Economics and Sociology. https://doi.org/10.14254/2071-789X.2017/10-1/11

Karakas, F., Manisaligil, A., \& Sarigollu, E. (2015). Management learning at the speed of life: Designing reflective, creative, and collaborative spaces for millenials. International Journal of Management Education.

https://doi.org/10.1016/j.ijme.2015.07.001

KPMG. (2017). Meet the Millennials. In KPMG. 
Kreemers, L. M., van Hooft, E. A. J., \& van Vianen, A. E. M. (2018). Dealing with negative job search experiences: The beneficial role of self-compassion for job seekers' affective responses. Journal of Vocational Behavior. https://doi.org/10.1016/j.jvb.2018.02.001

Leung, A. S. m., \& Clegg, S. R. (2001). The career motivation of female executives in the Hong Kong public sector. Women in Management Review. https://doi.org/10.1108/09649420110380247

Lykins, L., \& Pace, A. (2013). Mastering Millenial: Leadership development. T+D. https://doi.org/10.1177/1742715011407388

Mau, W. C. J. (2004). Cultural dimensions of career decision-making difficulties. Career Development Quarterly. https://doi.org/10.1002/j.2161-0045.2004.tb00656.x

Miller, M. B., Hodge, K. H., Brandt, A., \& Schneider, E. A. (2013). The Young and the Restless: Gen Y'ers in the Workplace! Are You Prepared? FDCC Quarterly.

Mitchell, A. (2012). Understanding generational gaps to improve faculty-student relationships. Teaching and Learning in Nursing. https://doi.org/10.1016/j.teln.2012.01.003

Moore, C. (2010). Teaching digital natives: Partnering for real learning. International Journal for Educational Integrity.

Nagy, J., Oláh, J., Erdei, E., Máté, D., \& Popp, J. (2018). The role and impact of industry 4.0 and the internet of things on the business strategy of the value chain-the case of hungary. Sustainability (Switzerland).

https://doi.org/10.3390/su10103491

Ng, E. S. W., Schweitzer, L., \& Lyons, S. T. (2010). New generation, great expectations: A field study of the millennial generation. Journal of Business and Psychology. https://doi.org/10.1007/s10869-010-9159-4

Ordun, G., \& Akun, A. (2016). Personality Characteristics and Emotional Intelligence Levels of Millenials: A Study in Turkish Context. Journal of Economic and Social Studies. https://doi.org/10.14706/jecoss16614

Osipow, S. H., \& Gati, I. (1998). Construct and concurrent validity of the career decision-making difficulties questionnaire. Journal of Career Assessment. https://doi.org/10.1177/106907279800600305

Park, K., \& Rim, H. (2019). Social media hoaxes, political ideology, and the role of issue confidence. Telematics and Informatics. https://doi.org/10.1016/j.tele.2018.11.001

Presnky, M. (2005). Teaching digital natives: Partnering for real learning. International Journal for Educational Integrity.

Price, S. L., McGillis Hall, L., Murphy, G. T., \& Pierce, B. (2018). Evolving career choice narratives of new graduate nurses. Nurse Education in Practice. https://doi.org/10.1016/j.nepr.2017.10.007

Purani, K., Kumar, D. S., \& Sahadev, S. (2019). e-Loyalty among millennials: Personal characteristics and social influences. Journal of Retailing and Consumer Services. https://doi.org/10.1016/j.jretconser.2019.02.006

Queiri, A., Dwaikatt, N., Fadzilah, W., Yusoff, W., \& Dwaikat, N. (2015). Explaining Generation-Y Employees' Turnover in Malaysian Context Impact of R\&amp;D Outsourcing in Global Enterprises View project Explaining Generation-Y Employees' Turnover in Malaysian Context. Asian Social Science.

https://doi.org/10.5539/ass.v11n10p126

Rastati, R. (2018). MEDIA LITERASI BAGI DIGITAL NATIVES: PERSPEKTIF GENERASI Z DI JAKARTA. Jurnal Kwangsan. https://doi.org/10.31800/jkwangsan-jtp.v6n1.p43--57

Salami, S. O. (2010). Gender as a moderator of relation between emotional intelligence and career development. US-China Education Review.

Santos, A., Wang, W., \& Lewis, J. (2018). Emotional intelligence and career decision-making difficulties: The mediating role of career decision self-efficacy. Journal of Vocational Behavior.

https://doi.org/10.1016/j.jvb.2018.05.008

Sholikhati, K. (2018). SOCIAL MEDIA, SOCIAL COMPETENCE DAN REMAJA. Jurnal Ilmiah LISKI (Lingkar Studi Komunikasi). https://doi.org/10.25124/liski.v1i2.819

Sidiropoulou-Dimakakou, D., Mylonas, K., Argyropoulou, K., \& Drosos, N. (2013). Career decision-making characteristics of primary education students in Greece. International Education Studies. https://doi.org/10.5539/ies.v6n5p22

Sovet, L., \& Metz, A. J. (2014). Parenting styles and career decision-making among French and Korean adolescents. Journal of Vocational Behavior. https://doi.org/10.1016/j.jvb.2014.02.002 
Spitzer, B., Morel, V., Buvat, J., \& Kanakadandi, S. (2015). THE DIGITAL TALENT GAP. DEVELOPING SKILLS FOR TODAY'S DIGITAL ORGANIZATIONS. ICERI2015: 8TH INTERNATIONAL CONFERENCE OF EDUCATION, RESEARCH AND INNOVATION.

Stonebraker, I., Maybee, C., \& Chapman, J. (2019). Undergraduate students' experiences of using information at the career fair: A phenomenographic study conducted by the libraries and career center. Journal of Academic Librarianship. https://doi.org/10.1016/j.acalib.2019.05.002

Storme, M., \& Celik, P. (2018). Career Exploration and Career Decision-Making Difficulties: The Moderating Role of Creative Self-Efficacy. Journal of Career Assessment. https://doi.org/10.1177/1069072717714540

Strauss, K., Griffin, M. A., \& Parker, S. K. (2012). Future work selves: How salient hoped-for identities motivate proactive career behaviors. Journal of Applied Psychology. https://doi.org/10.1037/a0026423

Suyatna, H., \& Nurhasanah, Y. (2018). Sociopreneurship Sebagai Tren Karir Anak Muda. Jurnal Studi Pemuda. https://doi.org/10.22146/studipemudaugm.38011

Teck Heang Lee, 2012:149. (2012). Perceived Job Readiness of Business Students at the Institutes of Higher Learning in Malaysia. International Journal of Advances in Management and Economics.

Tien, H. L. S. (2005). The validation of the career decision-making difficulties scale in a Chinese culture. Journal of Career Assessment. https://doi.org/10.1177/1069072704270327

Viskovich, S., \& De George-Walker, L. (2019). An investigation of self-care related constructs in undergraduate psychology students: Self-compassion, mindfulness, self-awareness, and integrated self-knowledge. International Journal of Educational Research. https://doi.org/10.1016/j.ijer.2019.02.005

Waaijer, C. J. F., Sonneveld, H., Buitendijk, S. E., Van Bochove, C. A., \& Van Der Weijden, I. C. M. (2016). The role of gender in the employment, career perception and research performance of recent $\mathrm{PhD}$ graduates from Dutch universities. PLoS ONE. https://doi.org/10.1371/journal.pone.0164784

Willner, T., Gati, I., \& Guan, Y. (2015). Career decision-making profiles and career decision-making difficulties: A cross-cultural comparison among US, Israeli, and Chinese samples. Journal of Vocational Behavior.

https://doi.org/10.1016/j.jvb.2015.03.007 